\title{
Analisis Pengaruh Biaya Produksi Terhadap Harga Jual Pada PT Ultra Milk Jaya Industri Tbk Yang Terdaftar Di Bursa Efek Indonesia
}

\author{
Teti Purnama Sari ${ }^{1}$, Reva Maria Valianti ${ }^{2}$, Muhamad Aryo Arifin ${ }^{3}$ \\ ${ }^{1}$ Fakultas Ekonomi dan Bisnis Universitas PGRI Palembang, tetipurnama5508@gmail.com \\ ${ }^{2}$ F.Ekonomi dan Bisnis Universitas PGRI Palembang, revavalianti@univpgri-palembang.ac.id \\ ${ }^{3}$ Fakultas Ekonomi dan Bisnis Universitas PGRI Palembang, aryo.83arifin@gmail.com
}

\begin{abstract}
This study aims to determine the extent to which production costs affect the selling price. The methodology used in this research is PT Ultra Milk Jaya IndustriTbk. Data collection methods used are literature study methods and documentation methods. The population used in this study is PT Ultra Milk Jaya Industri, Tbk, the sample used in this study is the PT Ultra Milk Jaya IndustriTbk Production Cost Report 2014-2018. While the data analysis method used is descriptive qualitative method using simple linear regression analysis using the SPSS 22 tool. From the research results obtained by a simple linear regression equation, it can be seen that production costs have a large (positive) effect on selling prices. This can be shown from the regri equation $Y=4.4 E+12+3.087$ which means that any increase in production costs will be followed by an increase in selling prices, on the other hand, if production costs decrease, it will also be followed by a decrease in selling prices. The effect of production costs on selling prices in this study amounted to $80.5 \%$ and the remaining $19.95 \%$ was influenced by other factors such as competition in the market and consumer tastes.
\end{abstract}

Keywords: Production Costs and SellingPrices.

\begin{abstract}
ABSTRAK
Penelitian ini bertujuan untuk sejauh mana biaya produksi berpengaruh terhadap harga jual. Metodelogi yang digunaksan dalam penelitian ini adalah PT Ultra Milk Jaya Industri Tbk. metode pengumpulan data yang digunakan adalah metode studi pustaka dan metode dokumentasi. Populasi yang digunakan pada penelitian ini adalah PT Ultra Milk Jaya Industri, Tbk, sampel yang digunakan pada penelitian ini adalah Laporan Biaya Produksi PT Ultra Milk Jaya Industri Tbk tahun 2014-2018. Sedangkan metode analisis data yang digunakan adalah metode deskriptif kualitatif dengan menggunakan analisis Regresi linier sederhana dengan menggunakan alat bantu SPSS 22. Dari hasil penelitian diperoleh persamaan regresi linier sederhana dapat diketahui bahwa biaya produksi memiliki pengaruh yang besar (Positif) terhadap harga jual. Hal ini dapat ditunjukan dari persamaan regri $Y=4,4^{E}+12+3,087$ yang memiliki arti bahwa setiap kenaikan biaya produksi akan diikuti pula dengan kenaikan harga jual, sebaliknya jika biaya produksi menurun akan diikuti pula dengan penurunan harga jual. Pengaruh biaya produksi terhadap harga jual dalam penelitian ini adalah sebesar $80,5 \%$ dan sisanya $19,95 \%$ dipengaruhi oleh faktor lain seperti persaingan di pasar dan selera konsumen.
\end{abstract}

Kata Kunci : Biaya Produksi dan Harga Jual.

\section{A. PENDAHULUAN}

Pada umumnya suatu perusahaan memiliki target atau tujuan untuk dicapai, salah satu tujuan yang di inginkan suatu perusahaan adalah untuk mendapatkan laba yang tinggi dengan meminimalkan pengeluaran biaya yang dilakukan dalam proses produksi. Laba atau rugi sering dimanfaatkan sebagai ukuran untuk menilai kinerja suatu perusahaan. Ukuran yang menjadi pembentuk laba adalah pendapatan dan biaya.

Mulyadi ( 2015:8) Biaya adalah pengorbanan sumber ekonomis yang diukur dalam satuan uang, yang telah terjadi, sedang terjadi atau kemunginana akan terjadi untuk tujuan tertentu. Biaya adalah faktor penting yang harus diperhatikan 
ketika perusahaan akan menghasilkan suatu produksi. Biaya pada suatu perusahaan dapat menggambarkan suatu kinerja perusahaan pada masa yang akan datang.

Akan tetapi masalah yang sering timbul dalam suatu perusahaan adalah perencanaan biaya oleh suatu perusahaan tidak sesuai dengan apa yang terjadi sesungguhnya, oleh karena itu untuk dapat mencapai produksi yang efesien, maka diperlukan suatu pengendalian terhadap biaya produksi yang akan dikeluarkan serta diperlukan manajemen yang baik dalam perusahaan.

Perusahaan PT Ultra Milk jaya Industri, Tbk. Merupakan perusahaan industri yang bergerak dalam bidang penjualan minuman, perusahaan ini berdiri karena adanya kemampuan untuk memproduksi suatu barang dan jasa yang dapat memenuhi kebutuhan masyarakat yang berupa minuman. Perusahaan Ultra Milk ini hanya memproduksi dan menjual produk susu saja. Untuk memenuhi selera masyarakat akan susu tersebut, perusahaan dituntut bisa menghasilkan barang dan jasa yang bernilai dan berkualitas baik

Tabel Biaya Produksi dan Harga Jual

\begin{tabular}{|l|c|c|c|c|c|c|}
\hline \multirow{2}{*}{ Tahun } & \multicolumn{3}{|c|}{ Biaya Produksi } & \multicolumn{3}{c|}{ Harga Jual } \\
\cline { 2 - 7 } & Triwulan I & Triwulan II & Triwulan II & Triwulan I & Triwulan II & Triwulan II \\
\hline 2016 & 736705382551 & 1506104033351 & 2.263 .537 .098 .874 & 1.107 .422 .042 .047 & 2.366 .070 .156 .658 & 3796189151241 \\
\hline 2017 & 739151830448 & 1461124820795 & 2.251 .284 .449 .891 & 1.299 .178 .942 .329 & 2.448 .943 .033 .556 & 3932358926331 \\
\hline 2018 & 823814000000 & 1674974000000 & 2.565 .083 .000 .000 & 1.432 .820 .000 .000 & 2.885 .837 .000 .000 & 4446754.000000 \\
\hline 2019 & 952807000000 & 1926848000000 & 2.946 .750 .000 .000 & 1.570 .693 .000 .000 & 3.269 .076 .000 .000 & 5041735000000 \\
\hline
\end{tabular}

Sumber : Laporan Keuangan Perusahaan PT. Ultra Milk Jaya Industri, Tbk

Pada tabel biaya produksi dan harga jual PT. Ultra Milk Jaya Industri, Tbk. perusahaan tersebut selalu berfluktuasi dimana pada tahun 2017 mengalami peningkatan penurunan pada triwulan ke 2 dalam biaya produksi. Tetapi pada tahun 2018-2019 perusahaan tersebut mengalami kenaikan yang cukup baik dalam memproduksi Maka dari itu perusahaan dituntut untuk dapat beroperasi dengan produktifitas dan efisiensi agar perusahaan dapat memproduksi dengan tepat jumlah, tepat waktu, dan biaya serendah mungkin. Sehingga perusahaan yang dapat beroperasi secara produktifitas dan efisiensi yang tinggi akan mempunyai daya saing yang rendah, dan menetapkan harga jual yang rendah.

Masalah yang sangat penting bagi perusahaan adalah pengambilan keputusan untuk menentukan harga jual, harga jual yang tidak tepat sering kali berakibat fatal pada masalah keuangan perusahaan dan akan mempengaruhi kontinuitas usaha tersebut. Ketidak tepatan tersebut akan menimbulkan resiko pada perusahaan, misalnya kerugian yang terus menerus atau menumpuknya barang digudang karena macetnya pemasaran. Karena itu perusahaan harus benar-benar menetapkan harga jualnya secara tepat dan baik, karena harga merupakan satu-satunya yang memberikan pemasukan atau pendapatan bagi perusahaan, biasanya harga yang rendah akan dipilih pembeli, sehingga dapat meningkatkan permintaan pasar.

Dari beberapa permasalahan tersebut, maka PT. Ultra Milk Jaya Industri. Tbk perlu melakukan analisis serta pengendalian terhadap tinggat harga jual perusahaan. Pengendalian dilakukan dengan menganalisis biaya produksi yang tercermin dari laporan keuangan, mengingat pentingnya harga jual terhadap suatu produksi. Berdasarkan penelitian terdahulu yang dilakukan oleh beberapa penelitian seperti Sherly Ramawaty dan Nita Agustina, dengan objek yang 
berbeda dimana hasil penelitiannya menunjukan bahwa biaya produksi memiliki pengaruh yang sangat kuat terhadap harga jual.

\section{B. KAJIAN TEORI}

\section{Pengertian Biaya Produksi}

Mulyadi (2015:14) Biaya Produksi adalah biaya-biaya yang terjadi untuk mengelola bahan baku menjadi produk jadi yang siap untuk dijual." Secara garis besar biaya produksi ini dibagi menjadi biaya bahan baku, biaya tenaga kerjalangsung, dan biaya overhead.

Sukirno (2013:208) Biaya Produksi dapat didefinisikan sebagai semua pengeluaran yang dilakukan oleh perusahaan untuk memperoleh faktor-faktor produksi dan bahan-bahan mentah yang akan digunakan untuk menciptakan barang-barang yang diproduksikan perusahaan tersebut.

Dari penjelasan diatas dapat disimpulkan bahwa biaya produksi adalah semua biaya yang dikeluarkan oleh perusahaan mulai dari bahan baku sampai pada produk yang sudah ingin dipasarkan atau sudah diproduksi.

\section{Elemen-elemen biaya produksi}

Biaya produksi digolongkan dalam tiga jenis yang merupakan elemenelemen utama dari biaya produksi, yang meliputi:

$>\quad$ Biaya Bahan Baku adalah besarnya nilai bahan baku yang dimasukkan ke dalam proses produksi untuk diubah menjadi barang jadi.

$>\quad$ Biaya Tenaga Kerja Langsung adalah besarnya biaya tenaga kerja yang secara langsung berhubungan dengan produksi barang jadi.

$>\quad$ Biaya Overhead pabrik adalah biaya-biaya yang etrjadi di pabrik selain biaya bahan baku maupun biaya tenaga kerja langsung.

\section{Metode pengumpulan harga pokok produksi}

Mulyadi (2014:17) Pengumpulan Harga Pokok Produksi sangat ditentukan oleh cara produksi. Adapun macam-macam jenis metode Pengmpulan Harga Pokok Produksi sebagai berikut:

$>\quad$ Metode penentuan harga pokok pesanan dilakukan dengan cara penentuan harga pokok yang membebankan biaya produksi untuk menjumlahkan produk tertentu yang dapat dipisahkan identitasnya.

$>\quad$ Metode harga pokok proses adalah pengumpulan harga pokok produksi yang digunakan perusahaan yang mengolah produknya secara massa.

\section{Metode Penentuan Harga Pokok Produksi}

Terdapat dua faktor pendekatan penentuan harga pokok produksi, yaitu:

$>$ Full Costing adalah metode penentuan harga pokok produksi yang memperhitungkan semua unsur biaya produksi ke dalam harga pokok produksi, yang terdiri dari bahan baku, biaya tenaga kerja langsung, dan biaya overhead pabrik baik yang tetap maupun variabel.

$>\quad$ Variabel Costing adalah metode penentuan harga pokok produksi yang hanya memperhitungkan biaya produksi yang berprilaku variabel ke dalam harga pokok produksi yang terdiri dari biaya bahan baku, biaya tenaga kerja langsung, dan biaya overhead pabrik namun hanya yang bersifat variabel. 


\section{Pengertian Harga Jual}

Supriyono (2011:318) harga jual adlah jumlah yang dibebankan oleh suatu unit usaha kepada pembeli atau pelanggan atas barang atau jasa yang dijual atau diserahkan. Sedangkan Mulyadi (2012:346) harga jual adalah besarnya harga yang akan dibebankan kepada konsumen yang diperoleh atau dihitung dari biaya produksi ditambah biaya non produksi dan laba yang diharapkan.

Dari definisi di atas dapat disimpulkan bahwa harga jual adalah sejumlah biaya yang dikeluarkan perusahaan untuk memperoduksi suatu barang atau jasa ditambah dengan presentase laba yang diinginkan perusahaan.

\section{Tujuan penentuan harga jual}

Dalam menentukan strategi harga, setiap perusahaan mungkin memiliki strategi pemasaran harga yang berbeda-beda. Namun untuk setiap strategi yang dijalankan masih memiliki satu tujuan yang sama. Tujuan untuk penetapan harga jual memiliki empat macam orientasi, yaitu:

a. Tujuan Berorientasi pada Laba, setiap perusahaan akan selalu mempertimbangkan untuk proses penetapan harga jual yang bertujuan untuk menghasilkan laba. Sebagai solusinya, para pengusaha akan lebih senang untuk menggunakan pendekatan target laba, yaitu besarnya laba usaha yang sudah benar-benar sesuai dengan sasaran laba sebelumnya (maksimisasi laba).

b. Tujuan Berorientasi pada Volume, penetapan harga yang bertujuan untuk menetapkan harga jual agar mampu mecapai target volume penjualan atau dari pangsa pasar tertentu.

c. Tujuan Berorientasi pada Citra (image), suatu perusahaan dapat dibentuk melalui penetapan harga. Perusahaan dapat menetapkan harga tinggi untuk membentuk atau mempertahankan citra prestisius. Sementara itu harga rendah dapat digunakan untuk membentuk citra nilai tertentu.

d. Tujuan Stabilisasi Harga, dalam pasar yang kosumennya sangat sensitif terhadap harga, bila perusahaan menurunkan harganya, maka para pesaingnya harus menurunkan pula harga mereka.

e. Tujuan-Tujuan Lainnya, harga dapat pula ditetapkan dengan tujuan mencegah masuknya pesaing, mempertahankan loyalitas pelanggan, mendukung penjualan ulang, atau menghindari campur tangan pemerintah.

\section{Faktor-fektor penentuan harga jual}

Dalam strategi pemasaran menentukan harga jual produk sangat penting dilakukan, karena meningkatkan laba jika salah dalam menentukan harga jual, dapat berdanpak pada keuntungan perusahaan, maka dari itu harus mengetahui faktor apa saja dalam penentuan harga jual, faktor tersebut terdiri dari 4 yaitu:

a. Konsumen/Pelanggan adalah prioritas utama, dimana konsumen sangat penting karna kelak akan menjadi pelanggan perusahaan.

b. Harga jual produk pesaing Sebelum perusahaan menetapkan harga ada baiknya perusahaan untuk melakukan riset di tempat yang akan dipasarkan, agar nantinya perusahaan mengetahui harga-harga yang ditetapkan oleh pesaing.

c. Biaya Hasil Produksi biaya yang dikeluarkan perusahaan dari awal pembuatan produk hingga akhir produk diperjual belikan haruslah 
diperhitungkan dengan benar. Jangan sampai perusahaan mengalami kerugian atas kesalahan dalam penetapan harga jual.

d. Keuntungan dari Penjualan Produk adalah tujuan dari setiappendiri perusahaan, keuntungan yang didapat haruslah menjadi profit ytersendiri bagi perusahaan.

\section{Metode Penentuan Harga Jual}

Mulyadi (2012:346) penentuan harga jual sebagai suatu nilai yang dapat menutupi seluruh biaya yang membebankan barang atau jasa yang dihasilkan ditambah dengan sejumlah keuntungan yang diinginkan oleh perusahaan. Penentuan harga jual yang terlalu tinggi akan menyebabkan konsumen beralih pada perusahaan pesaing yang menawarkan harga lebih murah dengan kualitas barang atau jasa yang relatif sama.

\section{METODE PENELITIAN}

Penelitian ini dilaksanakan di Bursa efek Indonesia, melalui website resmi BEl yang diambil dari Unika Musi Charitas Palembang, dengan waktu penelitian dilakukan pada bulan Januari 2020. Metode yang digunakan dalam penelitian ini adalah Deskriptif analisis. Populasi dalam penilitian ini adalah Laporan Biaya Produksi PT. Ultra Milk Jaya Industri. Tbk. Yang terdaftar di Bursa Efek Indonesia. Sampel pada penelitian ini yaitu data laporan keuangan pada PT. Ultra Milk Jaya Industri. Tbk. Yang terdaftar di Bursa Efek Indonesia periode 2016-2019 Teknik pengumpulan data merupakan cara yang digunakan peneliti untuk menumpulkan data. Teknik analisis data yang digunakan dalam penelitian ini adalah analisis data kuantittif, dengan menggunakan perhitungan yaitu dengan analisis regresi sederhana dan analisis koefisien determinasi. Sebagai berikut:

\section{Persamaan Regresi Sederhana}

$$
\mathbf{Y}=\mathbf{a}+\mathbf{b X}+\mathbf{e}
$$

Dengan Keterangan:

$Y=$ Harga Jual

$\mathrm{a}=$ Intersep (titik potong kurva terhadap sumbu $\mathrm{Y}$ )

$\mathrm{b}=$ kemiringan (slope) kurva linier

$\mathrm{X}=$ biaya Produksi

$\mathrm{e}=$ Error tern

\section{Koefisien Determinasi}

Koefisien determinasi diberi simbol $\left(\mathrm{r}^{2}\right)$. Koefisien determinasi adalah salah satu nilai statistik yang dapat digunakan untuk mengetahui apakah ada pengaruh antara dua variabel. Dari hasil tersebut menunjukan tingkat kejelasan yang dapat diberikan oleh model determinasi tersebut terhadapperubahan veriabel dependen. Secara umum nilai $r$ terletak pada nilai 0 sampai dengan $1(0<r<1)$.

\section{Uji Model t}

Uji model t pada dasarnya digunakan untuk menguji secara parsial masingmasing variabel. Hasil uji t dapat dilihat pada tabel coefficients pada kolom sig (significance). 


\section{HASIL DAN PEMBAHASAN}

Dari hasil regresi sederhana dengan bantuan program SPSS 22 pada penelitian ini diperoleh hasil persamaan regresi yang menyetakan persamaan pengaruh biaya produksi $\left(\mathrm{X}_{1}\right)$ terhadap Harga Jual $(\mathrm{Y})$ sebagai Berikut:

Tabel Analisis Pengaruh Biaya Produksi Terhadap Harga Jual

Coefficients $^{\mathrm{a}}$

\begin{tabular}{|c|c|c|c|c|c|}
\hline \multirow[b]{2}{*}{ Model } & \multicolumn{2}{|c|}{$\begin{array}{l}\text { Unstandardized } \\
\text { Coefficients }\end{array}$} & \multirow{2}{*}{$\begin{array}{c}\text { Standardized } \\
\text { Coefficients } \\
\text { Beta }\end{array}$} & \multirow[b]{2}{*}{$\mathrm{t}$} & \multirow[b]{2}{*}{ Sig. } \\
\hline & $\mathrm{B}$ & Std. Error & & & \\
\hline $\begin{array}{ll}1 & \text { (Constant) } \\
& \text { Biaya Produksi }\end{array}$ & $\begin{array}{r}8,8 \mathrm{E}+12 \\
1,746\end{array}$ & $\begin{array}{r}6,2 \mathrm{E}+12 \\
, 034 \\
\end{array}$ & 998 & $\begin{array}{l}-1,423 \\
50,651\end{array}$ & $\begin{array}{l}, 185 \\
, 000\end{array}$ \\
\hline
\end{tabular}

Sumber: Hasil Olahan Data SPSS 22

Dari persamaan regresi tersebut dapat disimpulkan bahwa setiap adanya kenaikan biaya produksi maka akan diikuti dengan kenaikan harga jual sebesar Rp.1,746.

\section{Hasil Koefisien Determinasi}

Tabel Model Koefisien Determinasi Model Summary

\begin{tabular}{|l|c|r|r|c|}
\hline Model & $\mathrm{R}$ & R Square & $\begin{array}{c}\text { Adjusted R } \\
\text { Square }\end{array}$ & $\begin{array}{c}\text { Std. Error of the } \\
\text { Estimate }\end{array}$ \\
\hline 1 &, $998^{\mathrm{a}}$ &, 996 &, 996 & 86000325910,254 \\
\hline
\end{tabular}

Sumber: Hasil Olahan Data SPSS 22

Dari hasil analisis regresi tersebut diperoleh persamaan pengaruh biaya produksi $(X)$ terhadap harga jual $(Y)$ yaitu: $Y=48,8^{E}+12+1,746$. Sehingga diperoleh thitung sebesar 50,651 maka dapat diketahui bahwa thitung $=50.651>t_{\text {table }}$ 1,81 berarti terdapat adanya pengaruh biaya produksi terhadap harga jual sebesar $99 \%$.

\section{Metode Uji t}

\section{Tabel Model Uji t}

Coefficients $^{\mathrm{a}}$

\begin{tabular}{|c|c|c|c|c|c|}
\hline \multirow[b]{2}{*}{ Model } & \multicolumn{2}{|c|}{ Unstandardized Coefficients } & \multirow{2}{*}{$\begin{array}{c}\begin{array}{c}\text { Standardized } \\
\text { Coefficients }\end{array} \\
\text { Beta }\end{array}$} & \multirow[b]{2}{*}{$\mathrm{t}$} & \multirow[b]{2}{*}{ Sig. } \\
\hline & $\mathrm{B}$ & Std. Error & & & \\
\hline 1 (Constant) & $-88474555323,472$ & 62192625919,181 & & $-1,423$ & 185 \\
\hline $\begin{array}{l}\text { Biaya } \\
\text { Produksi }\end{array}$ & 1,746 & ,034 & ,998 & 50,651 &, 000 \\
\hline
\end{tabular}

Sumber: Hasil Olahan Data SPSS 22 
Berdasarkan hasil perhitungan pada SPSS 22 pada table diatas diperoleh signifikan variabel biaya produksi 0,005 yang artinya $\mathrm{H} 0$ ditolak dan $\mathrm{H} 1$ diterima. Apabila permintaan dan pemesanan menurun dan juga biaya bahan baku akan menurun. Jika permintaan dan pesanan naik maka biaya bahan baku juga akan naik.

\section{Hasil data Biaya Produksi dan Harga Jual Pada Perusahaan PT. Ultra} Milk Jaya Industri Tbk,

Adapun pengeluaran yang digunakan untuk biaya produksi selama periode 2016-2019 yang terdiri dari: Biaya bahan Baku, Biaya Tenaga Kerja dan Biaya Overhead pabrik adalah sebagai berikut:

Tabel Biaya bahan Baku

\begin{tabular}{|c|c|c|c|}
\hline \multirow{2}{*}{ Tahun } & \multicolumn{3}{|c|}{ BiayaBahan Baku } \\
\cline { 2 - 4 } & Triwulan 1 & Triwulan II & Triwulan 3 \\
\hline 2016 & 601.832 .438 .652 & 1.231 .020 .819 .234 & 1.850 .778 .653 .383 \\
\hline 2017 & 606.363 .538 .536 & 1.181 .865 .348 .180 & 1.829 .241 .724 .236 \\
\hline 2018 & 683.270 .000 .000 & 1.386 .234 .000 .000 & 2.129 .566 .000 .000 \\
\hline 2019 & 791.619 .000 .000 & 1.591 .830 .000 .000 & 2.450 .128 .000 .000 \\
\hline
\end{tabular}

Sumber: Laporan Keuangan PT Ultra Milk Jaya Industri Tbk

Pengeluaran biaya tenaga kerja pada tahun 2016-2019 dilihat pada table berikut ini:

Tabel Biaya Tenaga Kerja

\begin{tabular}{|c|c|c|c|}
\hline \multirow{2}{*}{ Tahun } & \multicolumn{3}{|c|}{ Biaya Tenaga Kerja } \\
\cline { 2 - 4 } & Triwulan 1 & Triwulan II & Triwulan 3 \\
\hline 2016 & 7.829 .276 .398 & 18.080 .001 .645 & 25.624 .693 .187 \\
\hline 2017 & 6.963 .233 .251 & 16.668 .668 .279 & 23.688 .253 .354 \\
\hline 2018 & 6.841 .000 .000 & 15.779 .000 .000 & 22.529 .000 .000 \\
\hline 2019 & 8.818 .000 .000 & 20.635 .000 .000 & 28.856 .000 .000 \\
\hline
\end{tabular}

Sedangkan untuk pengeluaran biaya overhead pabrik pada tahun 2016-2019 dilihat pada table berikut:

Tabel Biaya Overhead Pabrik

\begin{tabular}{|c|c|c|c|}
\hline \multirow{2}{*}{ Tahun } & \multicolumn{3}{|c|}{ Biaya Overhead Pabrik } \\
\cline { 2 - 4 } & Triwulan 1 & Triwulan II & Triwulan 3 \\
\hline 2016 & 127.043 .667 .501 & 257.003 .212 .472 & 387.133 .752 .304 \\
\hline 2017 & 125.825 .058 .701 & 262.590 .804 .336 & 398.354 .998 .279 \\
\hline 2018 & 133.703 .000 .000 & 272.961 .000 .000 & 412.988 .000 .000 \\
\hline 2019 & 152.730 .000 .000 & 314.383 .000 .000 & 467.766 .000 .000 \\
\hline
\end{tabular}

Untuk mengetahui besarnya pengeluaran biaya produksi pada tahun 20162019 pada perusahaan PT Ultra Milk Jaya Industri Tbk, dapat dilihat dalam table berikut ini: 
Tabel Biaya Produksi

\begin{tabular}{|c|c|c|c|}
\hline \multirow{2}{*}{ Tahun } & \multicolumn{3}{|c|}{ BiayaProduksi } \\
\cline { 2 - 4 } & Triwulan 1 & Triwulan II & Triwulan 3 \\
\hline 2016 & 736.705 .382 .551 & 1.506 .104 .033 .351 & 2.263 .537 .098 .874 \\
\hline 2017 & 739.151 .830 .488 & 1.461 .124 .820 .795 & 2.251 .284 .449 .891 \\
\hline 2018 & 823.814 .000 .000 & 1.674 .974 .000 .000 & 2.565 .083 .000 .000 \\
\hline 2019 & 952.807 .000 .000 & 1.926 .848 .000 .000 & 2.946 .750 .000 .000 \\
\hline
\end{tabular}

Sumber: Laporan Keuangan PT Ultra Milk Jaya Industri Tbk

Pencapaian harga jual pada tahun 2016-2019 dapat dilihat dalam table berikut ini:

Tabel Harga Jual

\begin{tabular}{|c|c|c|c|}
\hline \multirow{2}{*}{ Tahun } & \multicolumn{3}{|c|}{ Harga Jual } \\
\cline { 2 - 4 } & Triwulan 1 & Triwulan II & Triwulan 3 \\
\hline 2016 & 1.107 .422 .042 .047 & 2.366 .070 .156 .658 & 3.796 .189 .151 .241 \\
\hline 2017 & 1.299 .178 .942 .329 & 2.448 .943 .033 .556 & $3.932 .358 . .926 .331$ \\
\hline 2018 & 1.432 .820 .000 .000 & 2.885 .837 .000 .000 & 4.446 .754 .000 .000 \\
\hline 2019 & 1.570 .693 .000 .000 & 3.269 .076 .000 .000 & 5.041 .735 .000 .000 \\
\hline
\end{tabular}

Sumber: Laporan Keuangan PT Ultra Milk Jaya Industri Tbk

Dari data harga jual PT Ultra Milk Jaya Industri Tbk, di atas selalu berfluktuasi setiap Triwulannya. Dimana tahun 2016 triwulan 1 mendapatkan harga jual sebesar Rp. 1.107.422.042.047 triwulan 2-3 mengalami kenaikan, tahun 2017 triwulan 1-3 harga jual yang didapat selalu mengalami peningkatan sebesar Rp.1.299.178.942.329 - Rp. 3.932.358..926.331, sedangkan pada tahun 2018 juga mengalami peningkatan pada harga jual sebesar Rp.1.432.820.000.000- Rp 4.446.754.000.000 dan pada tahun 2019 juga mengalami peningkatan setiap triwulannya sebesar Rp. 1.570.693.000.000 - Rp. 5.041.735.000.000.

Dari hasil penelitian mengenai biaya produksi tahun 2016-2019 pada perusahaan PT Ultra Milk Jaya Industri Tbk, terdiri dari 3 macam yaitu: Biaya Bahan Baku, Biaya Tenaga Kerja dan Biaya Overhead Pabrik sangat berpengaruh. Dimana pengaruh biaya produksi terhadap harga jual ini sebesar $99 \%$. Hal ini terjadi karena apabila pesanan dan permintaan menurun maka biaya produksi juga akan menurun, dan bila pesanan meningkat maka biaya produksi yang dikeluarkan akan meningkat.

Penelitian yang dilakukan oleh Nita Agustina (2017) dengan objek yang berbeda dimana $Y=-21271833,095+2,408 \mathrm{BBB}+-1,997 \mathrm{BTK}+18,049 \mathrm{BOP}=\mathrm{E}$ nilai tersebut mengidentifikasi bahwa jika variabel bahan baku, biaya tenaga kerja langsung, dan biaya overhead pabrik bernilai tetap maka variabel harga jual adalah sebesar -21271833,095

\section{E. KESIMPULAN DAN SARAN}

1) Kesimpulan

Dari hasil penelitian dan pembahasan, maka dapat disimpulkan bahwa biaya produksi memiliki pengaruh yang kuat dan besar terhadap harga jual yaitu sebesar $99 \%$ dan sisanya sebesar $1 \%$ dipengaruhi oleh variabel lain. Seperti permintaan di pangsa pasar dan persaingan pasar. Biaya yang digunakan untuk 
produksi dalam penilaian ini adalah Biaya Bahan Baku, Biaya Tenaga Kerja dan Biaya Overhead Pabrik.

2) Saran

Berdasarkan penelitian yang telah dilakukan, maka saran yang diberikan oleh peneliti adalah :

1. Perusahaan diharapkan dapat mempengaruhi kualitas produk agar menarik konsumen dengan cara penelitian kualitas di pangsa pasar supaya perusahaan dapat memberikan pelayanan yang terbaik bagi konsumen.

2. Untuk peneliti selanjutnya diharapkan agar dapat mengembangkan penelitian secara luas dan mendalam, menggunakan populasi yang luas terkait dengan biaya produksi dan harga jual dalampemasaranproduk yang ada di masyarakat

\section{DAFTAR PUSTAKA}

Edwar J, dkk, 2012 Manajemen Biaya: penekanan Strategis, Jakarta: Selemba Empat.

Halim, Abdul, 2010, Dasar-dasar Akuntansi Biaya, Edisi Keempat, Cetakan Ketiga, Yogyakarta: Penerbit BPFE

Mulyadi, 2011. Akuntansi Biaya. Yogyakarta: Universitas Gajah Mada. Jakarta: Selemba Empat.

2012. Akuntansi Biaya. Yogyakarta: Universitas Gajah Mada. Jakarta: Selemba Empat.

2014. Akuntansi Biaya. Yogyakarta: Universitas Gajah Mada. Jakarta: Selemba Empat.

2015. Akuntansi Biaya. Yogyakarta: Universitas Gajah Mada. Jakarta: Selemba Empat.

Riwayadi, 2014. Akuntansi Biaya. Jakarta. Selemba Empat.

Sukirno, 2015. Akuntansi Biaya. Jakarta: PT Raja Grafindo Persada

Siregar, Baldric, dkk. 2015 Akuntansi Biaya. Edisi 2.

Sugiyono, 2016, Metode Penelitian Kuantitatif, Kualitatif dan R\&D, Bandung: Alfabeta. Alfabeta.

Supriyono, R.A. 2010. Akuntansi Biaya: Pengumpulan Biaya dan Penentuan Harga Pokok. Edisi 2. Yogyakarta BPFE. 